\title{
PENGARUH EFIKASI PADA SIKAP GURU TERHADAP PENDIDIKAN INKLUSIF
}

\author{
Fellianti Muzdalifah* \\ Husna Zadat Billah** \\ *Fakultas Pendidikan Psikologi, Universitas Negeri Jakarta \\ ** Fakultas Pendidikan Psikologi, Universitas Negeri Jakarta
}

DOI: https://doi.org/10.21009/JPPP.061.04

\section{Alamat Korespondensi: \\ f_muzdalifah@yahoo.com}

\begin{abstract}
This study aims to understand the influence of teacher efficacy on teacher attitudes toward inclusive education. The variables studied were teacher efficacy as an independent variable $(X)$ and teacher attitudes toward inclusive education as a dependent variable (Y). The method used is quantitative research, with cluster sampling technique. Participants of this study were teachers from inclusive public elementary school in Jakarta $(N=164)$. The instrument used to measure teacher efficacy is Teacher Efficacy for Inclusive Practice (TEIP), while Multidimensional Attitudestoward Inclusive Education Scale (MATIES) was used to measure teacher attitudes toward inclusive education.Processing methods of data analysis in hypothesis testing using regression analysis. Results of this study showed there is influence of teacher efficacy on teacher attitudes toward inclusive education ( $p<\alpha ; 0,002<0,05)$, with the contribution of influence 0,05 (5\%). Therefore, in this study Ho is rejected and Ha accepted.
\end{abstract}

\section{Keywords}

teacher efficacy, teacher attitudes toward inclusive education, inclusive education

\section{Pendahuluan}

Pendidikan merupakan hak setiap warga negara Indonesia. Sebagaimana hal tersebut telah diatur dalam Undang-Undang No.20 tahun 2003 tentang Sistem Pendidikan Nasional BAB IV Bagian Kesatu Pasal 5 Ayat 1 yang menyebutkan bahwa "setiap warga negara mempunyai hak yang sama untuk memperoleh pendidikan yang bermutu". Hal ini menunjukkan bahwa pendidikan tidak membedakan status sosial dan ekonomi, jenis kelamin, suku, agama, ras dan tidak terkecuali bagi warga negara yang berkebutuhan khusus. Bagi warga negara yang berkebutuhan khusus juga disebutkan dalam UU No.20 tahun 2003 BAB IV Bagian Kesatu Pasal 5 Ayat 2 yang menunjukkan bahwa mereka tetap berhak mendapatkan pendidikan yang sesuai dengan kebutuhannya, yaitu "warga negara yang memiliki kelainan fisik, emosional, mental, intelektual, dan/atau sosial berhak memperoleh pendidikan khusus". Di Indonesia, pemerintah telah menyediakan berbagai fasilitas pendidikan bagi anak dengan kebutuhan khusus, salah satunya yaitu Sekolah Luar Biasa (SLB). Sekolah ini memberikan pelayanan khusus bagi anak dengan disabilitas, sehingga anak dapat memperoleh pelayanan pendidikan yang sesuai dengan kemampuan dan kebutuhan mereka. Dalam penyelenggaraan SLB, anak berkebutuhan khusus (ABK) belajar di lingkungan yang sama dengan kondisinya, sehingga ketika di sekolah mereka masih minim berinteraksi dengan anak pada umumnya. Hal ini menunjukkan bahwa masih terdapat batasan antara ABK dengan anak-anak pada umumnya, sehingga diperlukan bentuk pelayanan pendidikan 
yang lebih mengedepankan kesetaraan bagi anak berkebutuhan khusus.

Seiring berkembangnya pendidikan di Indonesia, pemerintah memperluas layanan pendidikan bagi anak berkebutuhan khusus yaitu dengan menyelenggarakan pendidikan inklusif. Pendidikan ini berbeda dengan SLB, pendidikan inklusif menyertakan murid reguler dengan murid berkebutuhan khusus dalam suasana dan proses pembelajaran yang sama. Pendidikan inklusif adalah sistem penyelenggaraan pendidikan yang memberikan kesempatan kepada semua peserta didik yang memiliki kelainan dan memiliki potensi kecerdasan dan/atau bakat istimewa untuk mengikuti pendidikan atau pembelajaran dalam satu lingkungan pendidikan secara bersama-sama dengan peserta didik pada umumnya (Peraturan Menteri Pendidikan Nasional Republik Indonesia Nomor 70 tahun 2009 pasal 1).

Pelayanan pendidikan tersebut diharapkan dapat meningkatkan interaksi antara murid pada umumnya dengan murid berkebutuhan khusus, mewujudkan kesamaan hak bagi ABK, serta mengatasi berbagai bentuk perlakuan diskriminatif pada $A B K$ sehingga mereka dapat lebih diterima secara terbuka oleh masyarakat.

Di Indonesia, pada tahun ajaran 2015/2016 sudah sebanyak 9.130 sekolah inklusif yang diselenggarakan oleh pemerintah (Setiarto, 2016). Sementara itu data yang bersumber dari Dinas Pendidikan Provinsi DKI Jakarta menyebutkan bahwa, pada tahun 2015 pemerintah telah menunjuk sebanyak 371 sekolah negeri reguler di Jakarta dari mulai tingkat TK, SD, SMP dan SMA/SMK yang menjadi penyelenggara pendidikan inklusif. Sekolah Dasar (SD) menjadi lembaga pendidikan yang paling banyak menyelenggarakan pendidikan inklusif, yaitu sebanyak 260 sekolah.

Meningkatnya jumlah SD Negeri inklusif tersebut tentu tidak menjamin meningkatnya kualitas, karena dalam penerapan pendidikan inklusif tentu tidak mudah. Berbagai persiapan patut dilakukan agar penyelenggaraannya dapat berjalan sesuai dengan mekanisme yang tepat. Selain itu masih ditemukan berbagai kendala dalam penyelenggaraan pendidikan inklusif khususnya di tingkat SD, terutama masalah pada guru reguler.
Berdasarkan penelitian yang dilakukan Tarnoto (2016) menunjukkan terdapat berbagai permasalahan pada guru yang muncul dalam pelaksanaan sekolah inklusif di tingkat SD. Permasalahan yang dikeluhkan diantaranya adalah kurangnya guru pendamping kelas, kurangnya kompetensi guru dalam menangani ABK, kurangnya pemahaman guru tentang $A B K$ dan sekolah inklusif, latar belakang pendidikan guru yang tidak sesuai, serta kurangnya kesabaran guru dalam menangani ABK.

Selain itu, berdasarkan hasil wawancara yang dilakukan pada tanggal 24 Maret 2016 dengan Bapak Irham Fauzi yang merupakan wali kelas 4 di SDN Inklusif Menteng Atas 04 Pagi, juga menunjukkan bahwa masih terdapat berbagai hambatan di SD Inklusif tempat beliau mengajar.

Beliau mengatakan bahwa jumlah murid berkebutuhan khusus di kelasnya sudah melampaui jumlah maksimal ABK yang se-harusnya diterima. Dengan banyaknya jumlah $\mathrm{ABK}$ di kelasnya tersebut, menurutnya dapat memecah konsentrasinya saat mengajar, karena ia juga harus mengajar murid reguler. Bapak Irham juga mengaku bahwa murid berkebutuhan khusus lebih mudah memancing emosinya.

Masalah pada guru reguler di SD Inklusif juga ditemukan berdasarkan wawancara pada tanggal 24 Maret 2016 dengan Ibu Eva yang merupakan wali kelas 1 di SDN Inklusi 01 Pela Mampang. Beliau mengatakan bahwa ia mengalami kesulitan karena tidak semua murid di kelasnya dapat dikondisikan dengan mudah, terutama murid berkebutuhan khusus. Terlebih lagi di sekolahnya hanya memiliki satu guru pendamping khusus yang memiliki latar belakang pendidikan luar biasa, sehingga jumlah tersebut menurutnya masih sangat kurang untuk membantunya mengajar di kelas. Beliau juga memper-masalahkan pelatihan yang diberikan pemerintah belum cukup memadai, sehingga pemahamannya mengenai cara memperlakukan ABK secara tepat masih minim, terlebih lagi para guru reguler di sekolah ini juga tidak memiliki latar belakang pendidikan luar biasa.

Berbagai kendala yang dialami oleh guru reguler di sekolah inklusif tersebut dikhawatirkan akan berdampak pada sikap yang diberikan oleh guru terhadap pendidikan inklusif. Sebagaimana United Nations Educational, Scientific, and 
Cultural Organization (UNESCO) menilai bahwa sikap guru juga dapat menjadi hambatan utama dalam pendidikan inklusif. Apabila guru tidak memiliki sikap yang positif terhadap murid berkebutuhan khusus, maka tidak mungkin anakanak tersebut dapat menerima pendidikan yang layak (www.unescobkk.org). Walaupun murid berkebutuhan khusus kerap sulit diatur dibandingkan murid pada umumnya serta lebih mudah memancing emosi guru, namun kendala tersebut diharapkan tidak memunculkan sikap guru yang negatif terhadap pendidikan inklusif yang menyertakan $\mathrm{ABK}$ untuk belajar di kelas reguler.

Myers (2014) menjelaskan bahwa sikap merupakan suatu reaksi evaluatif yang menyenangkan atau tidak menyenangkan terhadap sesuatu atau seseorang. Purwanto (1999) menjelaskan lebih lanjut mengenai sikap yang dapat berupa sikap positif dan negatif. Sikap positif adalah kecenderungan tindakan yang berupa mendekati, menyenangi dan mengharapkan objek tertentu, sedangkan sikap negatif adalah kecenderungan untuk menjauhi, menghindari, membenci, tidak menyukai objek tertentu.

Apabila dikaitkan dengan pendidikan inklusif, maka sikap guru terhadap pendidikan inklusif dapat diartikan sebagai reaksi yang menyenangkan atau tidak menyenangkan terkait penyelenggaraan program pendidikan inklusif, yang menyertakan anak berkebutuhan khusus untuk dapat belajar di sekolah reguler. Reaksi tersebut dapat berupa kecenderungan tindakan yang positif dalam menerima pendidikan inklusif. Sebaliknya, sikap negatif guru terhadap pendidikan inklusif yaitu guru akan cenderung tidak mengharapkan adanya pendidikan inklusif yang memberikan kesempatan bagi $\mathrm{ABK}$ untuk turut serta dalam proses pembelajaran di kelas reguler. Mahat (2008) mengartikan sikap guru terhadap pendidikan inklusif sebagai kecenderungan dalam merespon secara kognitif, afektif dan konatif terhadap pendidikan inklusif.

Beberapa penelitian menunjukkan hasil yang berbeda-beda. Berdasarkan penelitian yang dilakukan Khochen \& Radford (2012) menunjukkan bahwa secara keseluruhan guru di sekolah inklusif memiliki sikap yang positif. Sebanyak $76 \%$ guru dari total responden memandang bahwa individu berkebutuhan khusus sama dengan individu lain pada umumnya, kemudian mengenai sekolah khusus, sebanyak 56\% guru memandang bahwa penyediaan sekolah khusus tidak harus dipisahkan. Sementara itu, penelitian yang dilakukan oleh Alquraini (2012) menunjukkan hasil yang berbeda, yaitu guru memiliki pandangan yang negatif terhadap pendidikan inklusif, yaitu pada murid dengan gangguan intelektual yang parah.

Berdasarkan hasil penelitian sebelumnya yang dilakukan oleh Vaz, Wilson, Falkmer, Sim, Scott, Cordler \& Falkmer (2015) bahwa terdapat beberapa faktor yang dapat memprediksi sikap guru terhadap pendidikan inklusif, salah satunya yaitu efikasi diri dalam mengajar. Penelitian tersebut menunjukkan bahwa guru yang memiliki keyakinan atau efikasi diri yang rendah dalam mengajar, juga memiliki sikap yang lebih negatif terhadap pendidikan inklusif. Penelitian lain juga mengungkapkan hal yang serupa, bahwa efikasi diri berhubungan dengan sikap yang dimiliki guru tersebut. Savolainen, Engelbrecht, Nel \& Malinen (2012) mengatakan, semakin guru yakin akan kemampuannya dalam mengimplementasikan pendidikan inklusif, maka semakin positif sikap yang ditunjukkan guru terhadap pendidikan inklusif.

Efikasi diri adalah keyakinan bahwa seseorang dapat menguasai suatu situasi dan menghasilkan berbagai hasil positif (King, 2012), Menurut King, efikasi diri membantu orang dalam berbagai situasi yang tidak memuaskan dengan mendorong mereka untuk meyakini bahwa mereka dapat kuat.

Efikasi diri yang tinggi perlu dimiliki oleh seorang guru, karena efikasi diri pada guru akan berpengaruh besar terhadap kualitas pembelajaran murid (Santrock, 2007). Artinya, dalam proses belajar mengajar, guru terlebih dahulu harus yakin dengan kemampuannya, agar dapat memberikan pembelajaran yang berkualitas bagi murid.

Guru di sekolah inklusif penting memiliki efikasi diri yang tinggi, sebagaimana menurut Palmar (2006) bahwa efikasi diri dalam mengajar merupakan faktor penting yang memengaruhi kemampuan guru dalam mengajar murid disabilitas secara lebih efektif (Sharma, dkk., 2014). Penelitian yang dilakukan Hashim, Ghani, Ibrahim \& Zain (2014) menunjukkan bahwa guru reguler masih belum memiliki tingkat efikasi diri yang tinggi. Penelitiannya mengatakan terdapat permasalahan yang dialami guru reguler di 
sekolah inklusif, yaitu mereka tidak yakin dan tidak memiliki pengetahuan yang cukup dalam mengawasi murid berkebutuhan khusus.

Apabila guru tidak yakin dengan kemampuannya dalam menangani kondisi di dalam kelas, maka tidak dapat dipungkiri bahwa proses pembelajaran murid di sekolah inklusif akan tidak terlayani secara maksimal. Sebagaimana Bandura (1977) juga mengatakan bahwa efikasi diri penting untuk dikembangkan oleh guru yang mengajar di kelas inklusif, karena berperan dalam mengatur pelaksanaan mengajar di kelas (Loreman, Sharma \& Forlin, 2013).

Dalam penyelenggaraan pendidikan inklusif, perhatian yang lebih perlu diberikan bagi SD Negeri di Jakarta dengan program inklusif, karena SD Negeri merupakan jenjang pendidikan yang paling banyak menyelenggarakan sekolah inklusif di DKI Jakarta dibandingkan jenjang pendidikan lainnya seperti TK, SMP, dan SMA/SMK. Terlebih lagi, SD merupakan tingkat pendidikan yang paling penting karena di tingkat tersebut seseorang memperoleh pendidikan yang paling awal untuk dapat melanjutkan ke tingkat berikutnya. Selain itu, Jakarta yang menjadi ibukota negara diharapkan dapat menjadi contoh yang baik bagi sekolah inklusif di kota-kota lainnya di Indonesia.

Berdasarkan apa yang telah dipaparkan penulis mengenai efikasi diri pada guru yang turut berperan terhadap sikap guru terhadap pendidikan inklusif, maka penulis akan melakukan penelitian tentang pengaruh efikasi guru terhadap sikap guru terhadap pendidikan inklusif di SD Negeri Inklusif di Jakarta. Oleh karena itu, penulis memiliki pendapat bahwa efikasi diri pada guru dapat memberikan sumbangan pengaruh pada sikap guru terhadap pendidikan inklusif di SD Negeri Inklusif di Jakarta.

\section{Metode Penelitian}

Penelitian ini menggunakan metode penelitian kuantitatif. Populasi dalam penelitian ini adalah guru reguler dengan status wali kelas yang mengajar di Sekolah Dasar Negeri (SDN) Inklusif di DKI Jakarta. Teknik pengambilan sampel yang digunakan dalam penelitian ini adalah probability sampling. Jenis teknik probability sampling yang digunakan yaitu cluster sampling. Jumlah sampel dalam penelitian ini yaitu sebanyak 164 guru yang diperoleh dari 19 SD Negeri Inklusif di Jakarta Selatan dan Jakarta Timur.

Pengumpulan data pada penelitian ini menggunakan instrumen berupa kuesioner. Penyebaran kuesioner dilakukan secara langsung dengan mendatangi sekolah yang menjadi sampel penelitian. Kuesioner pada penelitian ini terdiri dari dua instrumen penelitian, yaitu instrument Multidimensional Attitude toward Inclusive Education Scale (MATIES) dikembangkan oleh Mahat (2008) yang digunakan untuk mengukur sikap guru terhadap pendidikan inklusif. Instrumen MATIES diukur melalui dimensi afektif, kognitif, dan perilaku.

Sementara itu, instrumen Teacher Efficacyfor Inclusive Practice (TEIP) yang dikembangkan oleh Sharma, Loreman \& Forlin (2011) digunakan untuk mengukur efikasi guru dalam konteks pendidikan inklusif. Instrumen TEIP diukur melalui dimensi Efficacy to Use Inclusive Instruction (efikasi dalam menggunakan strategi pengajaran inklusif), Efficacy in Collaboration (efikasi dalam bekerja sama dengan orangtua murid, kolega, dan profesi lainnya) dan Efficacy in Managing Behaviour (efikasi dalam menangani dan mencegah perilaku murid yang mengganggu).

Berdasarkan hasil uji validitas menunjukkan bahwa terdapat 15 item pada instrumen MATIES yang layak digunakan untuk penelitian, sedangkan pada instrumen TEIP terdapat 16 item yang layak digunakan untuk penelitian. Koefisien reliabilitas pada skala sikap guru terhadap pendidikan inklusif yaitu 0,96 , dan pada skala efikasi guru yaitu 0,84 . Uji statistik yang digunakan pada penelitian ini adalah analisis regresi linear satu prediktor. Analisis ini digunakan untuk mengetahui bagaimana prediksi variabel efikasi guru terhadap sikap guru terhadap pendidikan inklusif.

\section{Hasil Penelitian dan Diskusi}

Berdasarkan gambaran subjek penelitian, diketahui bahwa responden pada penelitian ini didominasi oleh subjek dengan jenis kelamin perempuan yaitu sebanyak 132 subjek penelitian (80,5\%), sedangkan subyek dengan jenis kelamin laki-laki yaitu sebanyak 32 subjek penelitian $(19,5 \%)$.

Kemudian berdasarkan usia, subjek penelitian didominasi oleh guru dengan rentang usia 51-60 
tahun yaitu sebanyak 66 orang $(40,2 \%)$, kemudian diikuti oleh subjek dengan rentang usia 31-40 tahun yaitu sebanyak 38 orang $(23,2 \%)$, rentang usia 21-30 tahun yang terdiri dari 33 orang (20,1\%), subjek dengan rentang usia 41-50 tahun yaitu sebanyak 26 orang $(15,9 \%)$ dan rentang usia 61-70 tahun yaitu 1 orang $(0,6 \%)$.

Sementara itu, gambaran subjek berdasarkan pendidikan terakhir menunjukkan bahwa subjek penelitian didominasi oleh guru yang memiliki pendidikan terakhir Strata 1 (S-1) yaitu sebanyak 156 orang $(95,1 \%)$, kemudian jumlah subjek yang memiliki pendidikan terakhir Diploma 3 (D-3) dan Strata 2 (S-2) memiliki jumlah yang sama yaitu 4 orang $(2,4 \%)$.

Pada penelitian ini juga diketahui bahwa mayoritas subjek penelitian belum pernah berinteraksi dengan penyandang disabilitas sebelum mengajar di sekolah inklusif, yaitu sebanyak 100 orang (61\%), sedangkan sebanyak 64 orang (39\%) sudah pernah berinteraksi dengan penyandang disabilitas sebelum mengajar di sekolah inklusif.

Selain itu dapat diketahui pula bahwa subjek penelitian didominasi oleh guru yang belum pernah mengajar ABK sebelum mengajar di sekolah inklusif yaitu sebanyak 140 orang $(85,4 \%)$, sedangkan subjek yang sudah pernah mengajar ABK sebelum mengajar di sekolah inklusif yaitu sebanyak 24 orang $(14,6 \%)$.

Mayoritas responden juga merasa fasilitas di sekolah inklusif tempat mereka mengajar belum memadai yaitu sebanyak 154 orang $(93,9 \%)$, sementara itu sebanyak 10 orang $(6,1 \%)$ merasa fasilitas di sekolah inklusif tempat mereka mengajar sudah memadai.

Hasil perhitungan juga diketahui bahwa jumlah subjek penelitian didominasi oleh guru yang tidak paham mengenai isi Peraturan Menteri Pendidikan Nasional yang membahas tentang pendidikan inklusif, yaitu sebanyak 113 orang $(68,9 \%)$. Sementara itu sebanyak 30 subjek penelitian $(18,3 \%)$ mengaku paham mengenai peraturan tersebut, serta sebanyak $21 \quad(12,8 \%)$ subjek penelitian memiliki jawaban lain di luar pilihan paham dan tidak paham.

Sementara itu, berdasarkan kepercayaan diri guru dalam mengajar $\mathrm{ABK}$ di kelas inklusif, sebanyak 86 subjek penelitian $(52,4 \%)$ merasa percaya diri dalam mengajar $\mathrm{ABK}$ di kelas inklusif, sebanyak $65(39,6 \%)$ subjek merasa tidak percaya diri, dan sebanyak 13 subjek $(7,9 \%)$ menjawab di luar opsi jawaban.

Berdasarkan perhitungan kategorisasi skor sikap guru terhadap pendidikan inklusif, menunjukkan bahwa subjek yang memiliki sikap yang positif terhadap pendidikan inklusif yaitu sebanyak 78 orang $(47,6 \%)$, sementara itu subjek yang memiliki sikap negatif terhadap pendidikan inklusi berjumlah lebih banyak yaitu 86 orang $(52,4 \%)$.

Sementara itu, berdasarkan perhitungan kategorisasi skor efikasi guru diperoleh bahwa subjek yang memiliki efikasi diri tinggi mendominasi yaitu sebanyak 91 orang $(55,5 \%)$, sementara itu pada subjek yang memiliki efikasi diri yang rendah yaitu sebanyak 73 orang $(44,5 \%)$. Dapat dikatakan bahwa, responden penelitian ini didominasi oleh guru yang memiliki sikap negatif, namun mayoritas guru memiliki efikasi diri yang tinggi.

Uji hipotesis pada penelitian ini dapat diperoleh hasil sebagai berikut:

a. Korelasi product moment menunjukkan nilai korelasi antara variabel efikasi guru dengan sikap guru terhadap pendididikan inklusif adalah senilai 0,235 , dan nilai signifikansi (p) sebesar 0,002. Berikut merupakan hasil perhitungan korelasi product moment:

Tabel 1. Korelasi Product Moment

\begin{tabular}{cccc}
\hline Variabel & $\begin{array}{c}\text { Perason } \\
\text { Correlation }\end{array}$ & $\begin{array}{c}\text { Sig. } \\
(\mathbf{p})\end{array}$ & $\begin{array}{c}\text { Taraf } \\
\text { Signifikansi }\end{array}$ \\
\hline $\begin{array}{c}\text { Efikasi Guru } \\
\text { dengan Sikap }\end{array}$ & & & \\
$\begin{array}{c}\text { Guru terhadap } \\
\text { Pendidikan } \\
\text { Inklusi }\end{array}$ & 0,235 & 0,002 & 0,05 \\
\hline
\end{tabular}


Berdasarkan tabel di atas dapat dikatakan bahwa nilai $\mathrm{p}$ lebih kecil daripada nilai $\alpha=0,05$, artinya terdapat hubungan antara efikasi guru dengan sikap guru terhadap pendidikan inklusif. b. Nilai konstanta untuk variabel efikasi guru dan sikap guru terhadap pendidikan inklusif memiliki nilai sebesar $-0,005$ dan koefisien regresi sebesar 0,120. Berikut merupakan hasil perhitungan koefisien analisis regresi:

Tabel 2. Koefisien Analisis Regresi

\begin{tabular}{ccc}
\hline Variabel & Konstanta & $\begin{array}{c}\text { Koefisien } \\
\text { Regresi }\end{array}$ \\
\hline Efikasi Guru & & \\
dan Sikap Guru & & 0,120 \\
terhadap & $-0,005$ & \\
Pendidikan & & \\
Inklusif & & \\
\hline
\end{tabular}

Berdasarkan data di atas, dapat ditentukan persamaan regresinya, yaitu sebagai berikut:

$$
\begin{gathered}
Y=a+b X \\
Y=-0,005+0,120 X
\end{gathered}
$$

Sikap Guru terhadap Pendidikan Inklusif $=-0,005$ + 0,120 Efikasi Guru

Berdasarkan persamaan tersebut, dapat diketahui bahwa jika sikap guru terhadap pendidikan inklusif (Y) mengalami kenaikan sebesar satu satuan, maka variabel efikasi guru (X) juga akan mengalami penambahan sebesar 0,120 . Selain itu, arah pengaruh yang ditunjukkan bersifat positif, artinya perubahan naik turunnya variabel sikap guru terhadap pendidikan inklusif searah dengan naik turunnya variabel efikasi guru. Dapat dikatakan bahwa apabila efikasi guru tinggi maka sikap guru terhadap pendidikan inklusif juga positif.

c. Uji Anova menunjukkan nilai $\mathrm{p}=0,002$ lebih kecil daripada nilai $\alpha=0,05$. Berdasarkan kriteria pengujian, Ha diterima dan Ho ditolak apabila nilai $\mathrm{p}<0,05$, sementara itu $\mathrm{Ha}$ ditolak dan Ho diterima apabila nilai $\mathrm{p}>0,05$. Berikut merupakan hasil perhitungan uji Anova analisis regresi:

Tabel 3. Uji ANOVA Analisis Regresi

\begin{tabular}{cccc}
\hline Variabel & $\begin{array}{c}\text { Sig. } \\
(\mathbf{p})\end{array}$ & $\begin{array}{c}\text { Taraf } \\
\text { Signifikansi }\end{array}$ & Interpretasi \\
\hline $\begin{array}{c}\text { Efikasi Guru dan } \\
\text { Sikap Guru terhadap }\end{array}$ & 0,002 & 0,05 & $\begin{array}{c}\text { Terdapat } \\
\text { pengaruh }\end{array}$ \\
\hline
\end{tabular}

Berdasarkan tabel di atas, dapat dikatakan bahwa Ha (Hipotesis alternatif) diterima, dan Ho (Hipotesis nol) ditolak, artinya terdapat peran efikasi guru terhadap sikap guru terhadap pendidikan inklusif. d. Sumbangan pengaruh (Adjusted $R$ Square) variabel efikasi guru terhadap sikap guru terhadap pendidikan inklusif yaitu sebesar $0,55(5 \%)$. Artinya, efikasi guru memengaruhi sikap guru terhadap pendidikan inklusif sebesar 5\%. Hasil perhitungan dapat dilihat pada tabel berikut:

Tabel 4. Uji Model Summary Analisis Regresi

\begin{tabular}{ccc}
\hline Variabel & R-Square & Adjusted R Square \\
\hline Efikasi Guru dan & & \\
Sikap Guru terhadap & 0,055 & 0,05 \\
Pendidikan Inklusif & & \\
\hline
\end{tabular}


Hasil perhitungan analisis regresi menunjukkan bahwa terdapat pengaruh efikasi guru terhadap sikap guru terhadap pendidikan inklusif.

Pada penelitian ini, efikasi guru memberi sumbangan pengaruh terhadap sikap guru terhadap pendidikan inklusif sebesar 5\%. Penelitian ini sejalan dengan penelitian yang dilakukan oleh Vaz, Wilson, Falkmer, Sim, Scott, Cordier, dan Falkmer (2015) yang menyatakan bahwa salah satu faktor yang memprediksi sikap guru terhadap pendidikan inklusif ialah efikasi guru dalam mengajar. Meskipun demikian, faktor efikasi guru dalam penelitian ini hanya memiliki sumbangan pengaruh terhadap sikap guru terhadap pendidikan inklusif sebesar 5\%, artinya 95\% lainnya dipengaruhi oleh faktor lain. Hasil penelitian yang dilakukan Vaz, dkk. (2015) menemukan bahwa terdapat empat faktor yang secara bersama-sama dapat memprediksi sikap guru terhadap pendidikan inklusif, yaitu usia, jenis kelamin, efikasi guru dan pelatihan. Dapat diasumsikan bahwa faktor-faktor lain yang turut memiliki sumbangan pengaruh terhadap sikap guru terhadap pendidikan inklusif selain efikasi guru adalah usia, jenis kelamin dan pelatihan pada guru.

Berdasarkan hasil analisis statistik diketahui bahwa arah hubungan antar variabel menunjukkan arah yang positif, namun hasil perhitungan kategorisasi efikasi guru menunjukkan lebih banyak guru dengan efikasi yang tinggi, sedangkan responden didominasi oleh guru yang memiliki sikap negatif terhadap pendidikan inklusif. Hal ini menunjukkan bahwa efikasi guru memang bukan merupakan faktor yang paling memprediksi sikap guru terhadap pendidikan inklusif, melainkan terdapat faktor-faktor lain sehingga hasil perhitungan kategorisasi menun-jukkan bahwa guru dengan sikap yang negatif memiliki jumlah yang lebih banyak, sedangkan mayoritas guru justru memiliki efikasi diri yang tinggi dalam mengajar.

Hasil penelitian ini menunjukkan bahwa sebanyak 78 responden $(47,6 \%)$ memiliki sikap yang positif terhadap pendidikan inklusif, sementara itu sebanyak 86 responden $(52,4 \%)$ memiliki sikap negatif terhadap pendidikan inklusif. Hal ini menunjukkan bahwa, lebih banyak guru yang memiliki sikap negatif terhadap pendidikan inklusif, yang artinya guru akan lebih menunjukkan perilaku menghindar terhadap pendidikan inklusif (Sharma, Loreman \& Forlin
2011). Berdasarkan hasil analisis data demografi menunjukkan bahwa responden pada penelitian ini didominasi oleh guru dengan umur 51-60 tahun yaitu sebanyak 66 orang $(40,2 \%)$. Menurut Vaz, dkk. (2015) guru dengan usia yang lebih tua cenderung memiliki sikap yang negatif terhadap pendidikan inklusif. Hal ini dikarenakan guru dengan usia yang lebih tua memiliki keterbatasan atau belum pernah memperoleh pelatihan dalam mengajar di pendidikan inklusif.

Penelitian yang dilakukan Schmidt \& Vrhovnik (2015) juga mengatakan bahwa guru dengan usia muda (20-30 tahun) memiliki tingkat persetujuan yang paling tinggi dalam mendukung murid berkebutuhan khusus, sedangkan guru dengan usia lebih dari 50 tahun memiliki tingkat persetujuan yang paling rendah. Hal tersebut disebabkan karena guru dengan usia muda memiliki pengetahuan yang lebih mengenai pendidikan inklusif di universitasnya dan lebih paham mengenai karakteristik murid berke-butuhan khusus, sehingga mereka memiliki pan-dangan yang lebih terbuka terhadap pendidikan inklusif.

Selain itu, pengalaman guru dalam berhadapan dengan murid berkebutuhan khusus juga dapat memengaruhi sikap yang dimiliki guru terhadap pendidikan inklusif. Berdasarkan penelitian Alquraini (2014) menunjukkan bahwa guru yang memiliki pengalaman mengajar ABK di sekolah inklusif, memiliki pandangan yang lebih positif. Sementara itu, pada penelitian ini menunjukkan bahwa mayoritas guru belum pernah memiliki pengalaman mengajar $\mathrm{ABK}$ dan juga belum pernah berinteraksi dengan ABK sehingga mayoritas responden pada penelitian ini menunjukkan sikap yang negatif terhadap pendidikan inklusif.

Selanjutnya, berdasarkan hasil perhitungan kategorisasi efikasi guru dapat diketahui bahwa terdapat 91 responden $(55,5 \%)$ yang termasuk ke dalam kategori efikasi diri yang tinggi, sedangkan pada kategori efikasi yang rendah terdapat 73 responden $(44,5 \%)$. Hal ini menunjukkan bahwa lebih banyak guru yang memiliki efikasi yang tinggi dalam menerapkan pendidikan inklusif. Artinya, mayoritas guru merasa yakin dengan kemampuannya dalam menggunakan strategi pengajaran inklusif secara efektif, guru juga merasa yakin untuk mampu bekerjasama dengan orangtua murid, profesi lain dan kolega, serta 
guru merasa yakin untuk dapat mencegah dan menangani perilaku murid yang mengganggu di kelas. Sebagaimana menurut Gibson \& Dembo (1984) bahwa guru yang memiliki perasaan efikasi diri yang tinggi akan dapat menggunakan strategi mengajar yang lebih baik (Gibson \& Dembo, 1984).

Menurut Loreman, Sharma, \& Forlin (2013) salah satu faktor yang memengaruhi efikasi guru dalam mengajar di kelas inklusif adalah kepercayaan diri dalam mengajar ABK. Tingkat kepercayaan diri dalam mengajar ABK akan sangat sesuai dengan efikasi guru dalam mengajar di kelas inklusif. Berdasarkan hasil data demografi pada penelitian ini menunjukkan bahwa mayoritas responden merasa percaya diri dalam mengajar ABK, yaitu sebanyak 86 responden $(52,4 \%)$, sedangkan sebanyak 65 responden $(39,6 \%)$ merasa tidak percaya diri, dan 13 responden $(7,9 \%)$ memiliki jawaban lain diluar opsi yang tersedia. Hal ini menunjukkan hasil yang hampir sesuai dengan jumlah responden yang memiliki efikasi diri yang tinggi yaitu sebanyak 91 responden $(55,5 \%)$.

\section{Kesimpulan}

Penelitian ini mengkaji pengaruh efikasi guru terhadap sikap guru terhadap pendidikann inklusif. Hasil pengujian statistik dari 164 responden, diperoleh kesimpulan bahwa terdapat pengaruh efikasi guru terhadap sikap guru terhadap pendidikan inklusif di SD Negeri Inklusif di Jakarta dengan arah korelasi yang positif. Efikasi guru memberikan sumbangan pengaruh terhadap sikap guru terhadap pendidikan inklusif yaitu sebesar 5\%.

\section{Daftar Pustaka}

Alquraini, T. A. (2012). Factors Related to Teachers' Attitudes Towards the Inclusive Education of Students with Severe Intellectual Disabilities in Riyadh, Saudi. Journal of Research inSpecial Educational Needs, Vol. 12, No. 3,170-182.

Dinas Pendidikan Provinsi DKI Jakarta. (2015). Daftar Sekolah Penyelenggara Pendidikan Inklusi Provinsi DKI Jakarta. Bersumber dari http://disdik.jakarta.go.id/download/
DATA/PPDB2015/Sekolah\%20Inklusif\% 202015.pdf. Diakses pada 5 Maret 2017.

Hashim, M.Z.B., Ghani, M.Z.B., Ibrahim, S., \& Zain, W.S.M. (2014). The Relationship Between Teachers' Self Efficacy and Attitudes Towards Inclusive Education in Pulau Pinang. International Journal of Research In Social Sciences, 4(7), 24-33.

Khochen, M., \& Radford, J. (2012). Attitudes of Teachers and Headteachers Towards Inclusion in Lebanon. International Journal ofInclusive Education, 16(2), 139-153.

King, A.L. (2012). Psikologi Umum. Sebuah Pandangan Apresiatif. Jakarta: Salemba Humanika.

Loreman, T., Sharma, U., \& Forlin, C. (2013). Do Pre-Service Teacher Feel Ready to Teach in Inclusive Classrooms? A Four Country Study of Teaching Self Efficacy. Australian Journal of Teacher Education. 38, 27-44.

Mahat, M. (2008). The Development of a Psychometrically-Sound Instrument to Measure Teachers' Multidimesional Attittudes Toward Inclusive Education. International Journal of Spesial Education, 23(1), 82-92.

Myers, D.G. (2014). Psikologi Sosial (10th Ed.). Jakarta: Salemba Humanika.

Peraturan Menteri Pendidikan Nasional Republik Indonesia Nomor 70 Tahun 2009. (n.d.). Bersumber dari http://kelembagaan. ristekdikti.go.id/wp-content/uploads/2016/ 11/Permen-No.-70-2009-tentangpendidiian-inklusif-memiliki-kelainankecerdasan.pdf. Diakses pada tanggal 18 Maret 2017.

Purwanto, H. (1999). Pengantar Perilaku Manusia untuk Keperawatan. Jakarta: EGC. 
Santrock, J.W. (2007). Psikologi Pendidikan (2nd ed.). Jakarta: Kencana.

Savolainen, H., Engelbrechtb, P., Nelc, M., \& Malinena, O. (2012). Understanding Teachers' Attitudes and Self-Efficacy in Inclusive Education: Implications for PreService and In-Service Teacher. European Journal of Special Needs Education, 27(1), 51-68.

Setiarto, B. (2016). Kebijakan Implementasi Program Pendidikan Inklusif. Retrieved from http://www.pustakaslbmtw.com/ downloads/INKLUSI-2.pdf. Diakses pada tanggal 18 Maret 2017

Sharma, U., Loreman, T., \& Forlin, C. (2011). Measuring Teacher Efficacy to Implement Inclusive Practices. Journal of Research in Special Education Needs. 1-10.

Sharma, U. Shaukat, S., \& Furlonger, B. (2014). Attitudes and Self-Efficacy of Pre-Service Teachers Toward Inclusion in Pakistan. Journal of Research in Special Educational Needs, 1-9.
Tarnoto, N. (2016). Permasalahan-Permasalahan yang Dihadapi Sekolah Penyelenggara Pendidikan Inklusi pada Tingkat SD. Humanitas, Vol. 13, No. 1, 50-61.

Undang-Undang Republik Indonesia No.20 tahun 2003 tentang Sistem Pendidikan Nasional. (n.d.). Bersumber dari http://pendis. kemenag.go.id/file/dokumen/uuno20th200 3ttgsisdiknas.pdf. Diakses pada tanggal 5 Maret 2017.

UNESCO. Barriers to inclusive education. Retrieved from http://www.unescobkk. org/education/inclusive-education/what-isinclusive-education/barriers-to-inclusiveeducation/. Diakses pada tanggal 18 Maret 2017.

Vaz, S., Wilson, N., Falkmer, M., Sim, A., Scott, M., Cordler, R., \& Falkmer, T. (2015). Factors Associated with Primary School Teachers' Attitudes Toward the Inclusion of Students with Disabilities. Inclusion of Students withDisabilities in School, 1-12. 